\title{
6
}

\section{Moiety Names in South-Eastern Australia: Distribution and Reconstructed History}

\author{
Harold Koch, Luise Hercus and Piers Kelly
}

\section{Introduction}

This report ${ }^{1}$ forms part of the project 'Skin and kin in Aboriginal Australia: linguistic and historical perspectives on the dynamics of social categories', whose object is to document and map the Australian systems of social category names and reconstruct their prehistory. ${ }^{2}$ Social category systems include subsections, sections and moieties. Here, we report on the moiety names in six of the terminological sets found in south-eastern Australiaidentified on the basis of (near-)identical names. ${ }^{3}$ Typically, these terminological sets extend over a number of different languages, including languages that are not closely related linguo-genetically to one another. Moreover, the terminologies may differ between languages that are closely related to one another. We do not discuss moiety names that co-occur

\footnotetext{
1 We thank Patrick McConvell, Ted Ryan and two anonymous reviewers for their helpful comments on earlier versions of this chapter, but take responsibility for the final content.

2 The project is funded by Australian Research Council grant no. DP120100632; chief investigators Patrick McConvell, Harold Koch, Jane Simpson; and partner investigator Laurent Dousset. See McConvell and Dousset (2012) for a description; the online database can be accessed at www.austkin.net.

3 We use 'system' to refer to kinds of social categorisations (moiety, section and subsection) and 'set' for the terms that occur in languages using the same (or cognate) names in their categorisation system.
} 
with section names in systems of four sections (such as the Queensland General system discussed in Chapter 8) or eight subsections. ${ }^{4}$ Thus, we will be primarily discussing six pairs of terms - that is 12 words-plus some minor sets that occur on the fringes of the main ones.

For each of the six sets of terms, plus their variants, we discuss:

- the sources of the information

- the linguistic forms, as spelled in the sources, phonemicised by linguists and spelled in the standardised orthography used by the AustKin project ${ }^{5}$

- the languages in which they occur-the languages as named in the sources, as well as the modern language names ${ }^{6}$

- the linguistic genetic groups $s^{7}$ that the languages belong to

- the name of the terminology set/type/area as given in the literature

- a map of its distribution ${ }^{8}$

- a comparison of the distribution of the set of moiety terms to that of the genetic subgroup

- whether the moiety names have meanings (other than denoting a social category) in their language.

We then compare our distributions with other summaries in the literature. Using methods from historical linguistics, we offer our reasoning in regard to the historical processes that have led to the distribution of moiety terms across linguo-genetic groups. We argue that cultural borrowing was the main mechanism that spread the terminological sets. We offer indications of the direction of these spreads, which is displayed in Figure 22. Evidence from the etymology of names is sparse, but we suggest that this evidence tends to support an expansion from the Murray-Darling area.

4 It is not clear in such cases whether the section names date from before the (sub)section names or were adopted concurrently with or subsequently to the latter.

5 This orthographic system uses voiceless symbols ( $p, t$ and $k$ ) for stop consonants; digraphs $n g$ for the velar nasal; th, $n h$ and $l h$ for laminodentals; $t y, n y$ and $l y$ for palatals; and up to three different symbols for the different kinds of rhotic ( $r$-like) sounds: $r$ for the English-like glide; $r r$ for a tap; $r r h$ for a trill that contrasts with the tap; for languages that do not distinguish the latter two, $r r$ is used for a sound that can either be a tap or trill.

6 We use the spelling of our sources when reporting their information, otherwise we use the version given in the AustKin database, accessed at austkin.net/index.php?loc=list_languages.

7 All the relevant groupings are subgroups of the Pama-Nyungan family of Australian languages or subgroups of these subgroups (e.g. Central Karnic and Western Kulin).

8 The maps were produced in the first instance by Piers Kelly and revised by Billy McConvell. Boundaries are approximate only and maps are based on information in AUSTLANG, accessed at austlang.aiatsis.gov.au. 
The terminological sets we discuss are summarised in Table 14, where we present the terms, our general name for the terminological set and the section of this chapter where each is discussed. It should be stated at the outset that all except the Central Victorian set involve matrimoieties, whereas the Central Victorian terms refer to patrimoieties. ${ }^{9}$ The names in Table 14 are ordered insofar as possible to show the pragmatic equivalences (see Chapter 1) across systems, based on the following authorities. Thiniwa $=$ Matharri follows Howitt (1996 [1904], p. 91) rather than the contradictory indication in Howitt (1996 [1904], p. 138). Wuthurru = Matharri accords with Howitt (1996 [1904], p. 192). Wuthurru = Thiniwa follows Elkin's field notes (see section 'The SouthWest Queensland Set'). Kilparra = Kulparru is based on Howitt's (1996 [1904], p. 138) statement that 'it seems that Kulpuru is the equivalent of Kilpara, and Tiniwa of Mukwara'. Kilparra = Kurukity is based on Howitt (1996 [1904], p. 137). Any statements about equivalences between the Central Victorian patrilineal moieties and any of the other matrimoieties are suspect (see subsection 'The Makwara and Kilparra Set'). ${ }^{10}$

Table 14: Summary of terminological sets.

\begin{tabular}{|l|l|l|}
\hline Term & Label & Section \\
\hline Matharri \& Kararrhu & South Australian & The South Australian Set \\
\hline Thiniwa \& Kulparru & Cooper Basin & The Cooper Basin Set \\
\hline Wuthurru \& Parrkatha & South-West Queensland & The South-West Queensland Set \\
\hline Makwara \& Kilparra & Darling River & The Darling River Set \\
\hline Waang \& Bunjil & Central Victorian & The Central Victorian Set \\
\hline Kamaty/Kapaty \& Kurukity & Western Victorian & The Western Victorian Set \\
\hline
\end{tabular}

Source: Authors' work.

\section{The South Australian Set}

One set of moiety terminologies was identified by Howitt (1996 [1904]) as characteristic of the 'Lake Eyre group' of tribes, exemplified by the Dieri [Diyari] of South Australia. Howitt gave the Diyari names as Matteri and Kararu. We spell the names as Matharri and Kararrhu, adapting Austin's (1981, p. 10) phonological analysis of the names to the standardised

9 Testart (1978) claimed that matrimoieties are prior in all of Australia.

10 For example, Howitt (1996 [1904], p 138): 'In the south-west of Victoria ... Kroki is equal to Bunjil and Kumitch to Waang'. 
AustKin orthography. R. H. Mathews (1905, p. 49) called the group characterised by this set of terms the 'Parnkalla nation, whose social divisions are Kirraroo and Matturi'-Parnkalla being the name of a tribe and language in the northern Eyre Peninsula. Elkin (1931, pp. 51, 53) delineated a 'Lakes group' of South Australian tribes and described the distribution of the Matari and Kararu moiety names as extending from the Wonkamala [Wangkamanha] and Wongkongaru [Wangkangurru] in the north to the Ngaluri [Ngadjuri], Pankala [Parnkalla] and Naua [Nauo] in the south.

Many of the languages spoken by groups that have this set of moiety names belong to the Thura-Yura subgroup of languages, as defined by Simpson and Hercus (2004). There is no question concerning the northern languages: Kuyani, Adnyamathanha (where Kararrhu occurs as Ararrhu, lacking the initial $k$, as a consequence of a regular sound change in this language), Nukunu ${ }^{11}$ and Parnkalla (now normally spelled Banggala). There is some question about how far west this set extends. For the poorly attested Nauo language, once spoken in the southern Eyre Peninsula, no terms are cited in Hercus (1999) or Hercus and Simpson (2001). However, Howitt's 1904 map includes this region within his matrimoiety area, and Elkin (1931, p. 45) included 'Naua' in the Matari and Kararu groups. Wirangu is the westernmost of the Thura-Yura languages. Hercus (1999, p. 1) stated that 'Wirangu people had the same matrilineal moiety system as their eastern neighbours, with a division into madhaRi and gaRarru', and cited several kinds of evidence to support this claim. This is consistent with Howitt's (1996 [1904], p. 129) claim: 'The tribes which live on the coast between Eucla and Spencer's Gulf evidently belong to the Lake Eyre group, having the same class names in variations of Matteri and Kararu'. The southern part of the Thura-Yura region presents a different picture. Simpson and Hercus (2004, pp. 181-2) stated: 'All but the southernmost people (Kaurna, Narangga [Narungga] and Ngadjuri ${ }^{12}$ ) ... had a matrilineal moiety system, the main features of which were shared with Karnic people, with moieties, named Mathari and Karraru [sic]'.

11 The sharp social difference between the Nukunu and their neighbours is highlighted by the fact that as recently as the 1960s, Hercus was told by a Nukunu man that his people regarded the marriage practices of their neighbours as incestuous: 'Those people in the east they were marrying the wrong way, marrying their sisters!' (Hercus 1992a, p. 11).

12 Elkin (1931, p. 53) included in his Matari-Kararu group 'Ngaluri', which is identified by Hercus (1992a, p. 24) as Ngalyuri: 'i.e. Ngadjuri'. The presence of moieties is also presupposed by Berndt's (1939, p. 459) comment: 'In the Ngadjuri tribe the curlew was of the Gararu moiety; the owl's moiety was unidentified, but was probably the other one, Matêri. These moieties were exogamous'. 


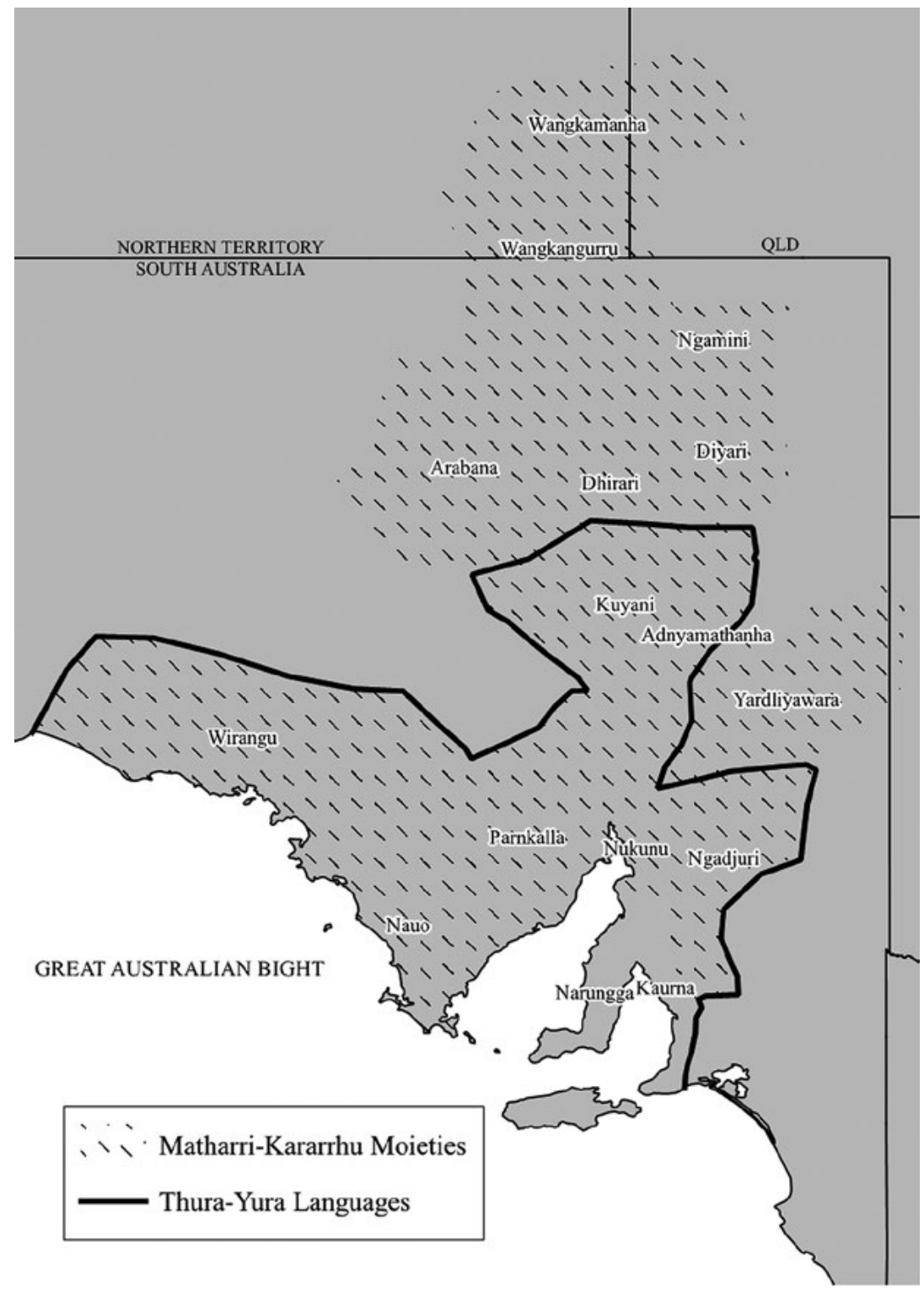

Figure 17: Matharri-Kararrhu moieties, plus Thura-Yura languages.

Source: Authors' work. 
Figure 17 indicates the distribution of the Matharri and Kararrhu moiety names, ${ }^{13}$ as well as all the Thura-Yura languages_-including the southernmost Kaurna and Narangga, in which these names are not found.

In addition to most, but not all, Thura-Yura languages, these moiety names are found in languages of the Yarli and Karnic subgroups. They occur in Yardliyawarra (according to Hercus's information), which is a member of the small Yarli subgroup and adjacent to Adnyamathanha (of the Thura-Yura group)—with whom its speakers have the closest cultural associations (Hercus \& Austin 2004, p. 211). ${ }^{14}$ The Karnic languages are a large subgroup (Bowern 2001) located to the north and north-east of the Thura-Yura languages. The Western Karnic languages, Arabana and Wangkangurru, have the Matharri and Kararrhu terms, plus the adjacent Wonkamala [= Wangkamanha] of Northern Karnic; however, the names are found in only some of the languages usually classified as Central Karnic_namely Diyari, Dhirari [Dhirrari] and Ngamini. ${ }^{15}$ The other Central Karnic languages, as well as Northern and Eastern Karnic, have other moiety naming terms-either the Cooper Basin set (see section 'The Cooper Basin Set') or the south-western Queensland set (see section 'The South-West Queensland Set'). Figure 18 shows all the Karnic languages: Karnic languages that have the Matharri and Kararrhu terminology and those with Kulpurru and Thiniwa, as well as all languages with Parrkatha and Wuthurru.

13 This area partially overlaps with that of the 'Dieri kinship system', in which the 'mother's mother' term also functions as a sibling term and the 'father's mother' term as 'cross-cousin' (see McConvell 2013, pp. 169-71; Scheffler 1978, pp. 365-84).

14 However, note that Yardliyawarra does not share with Adnyamathanha the absence of initial $k$.

15 Howitt (1996 [1904], p. 95) also included Yaurorka [Yawarrawarrka] in this grouping; however, Mathews and Elkin assigned it to what we are calling the Cooper Basin set (see section 'The Cooper Basin Set'). Breen (2004a, p. 4) alerted us to the fact that Howitt's Yandruwandha and Yawarrawarrka data are not always reliable, sometimes including material that is Diyari or Ngamini. 


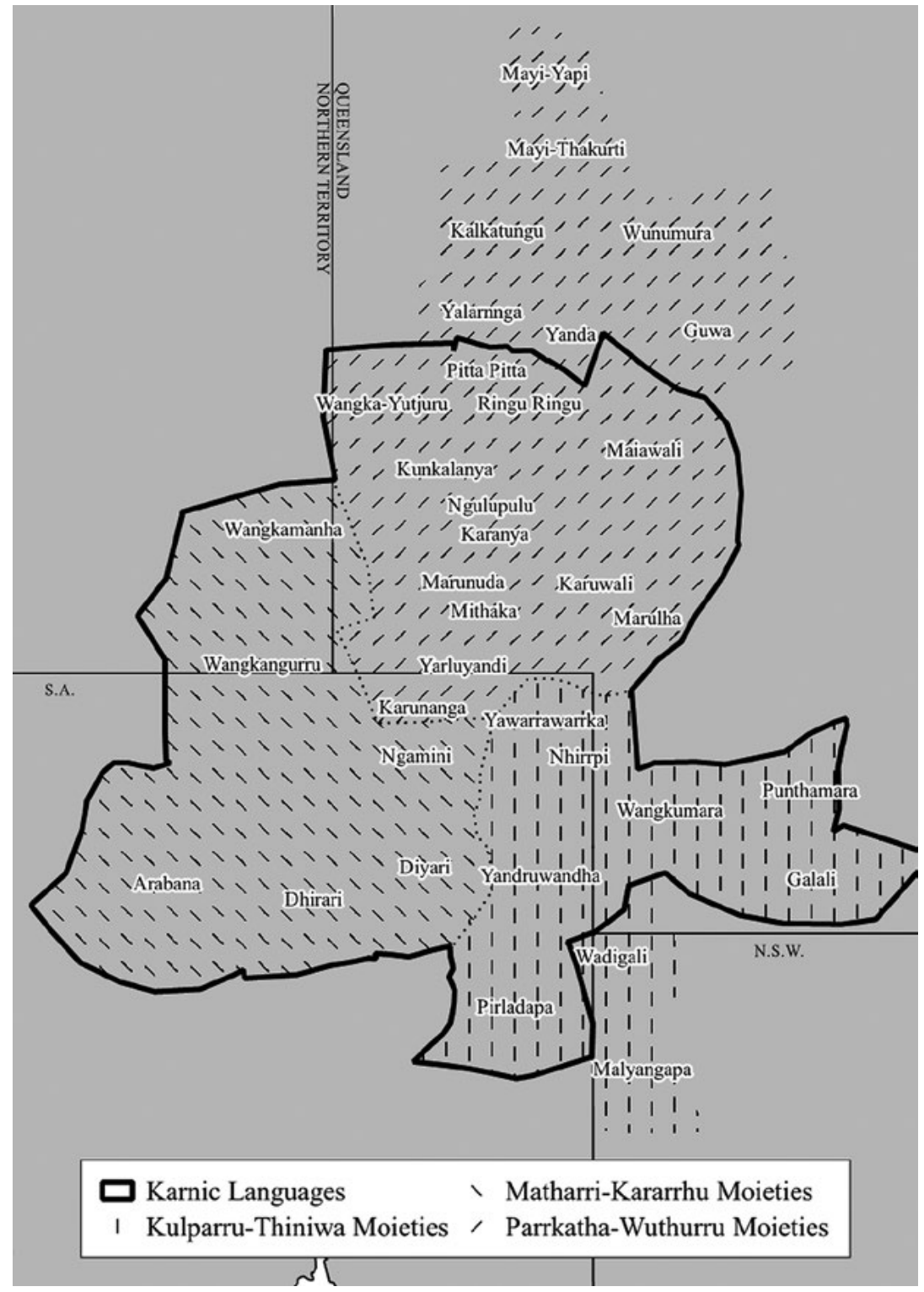

Figure 18: Karnic languages; three moiety sets.

Source: Authors' work. 


\section{The Cooper Basin Set}

To the east of Diyari, in an area centred on the Cooper Creek, there is another terminological set characterised by the moiety names established in their modern form as Kulparru and Thiniwa by Wafer and Lissarrague (2008, pp. 423, 428, cf. 458). ${ }^{16}$ This echoes R. H. Mathews (1905, p. 51), who called the peoples with these names the 'Wonkamurra nation'; he had earlier called them the 'Yowerawarrika nation' (Mathews 1900, p. 83). ${ }^{17}$ The languages with this set of terms include:

- Central Karnic languages from South Australia: Pirladapa ${ }^{18}$ (Elkin 1931, p. 53), Yandruwandha (Breen 2004b, p. 22; Elkin 1931, p. 53; Howitt 1996 [1904], pp. 91-2; Mathews 1905, p. 51,), including the Nhirrpi dialect from the hills north of Nappamerri (see Bowern 1999), Yawarrawarrka (Elkin 1931, p. 53; Mathews 1905, p. 51)

- Eastern Karnic languages ${ }^{19}$ of Queensland: Wangkumara (Mathews 1905, p. 51; Robertson $1984^{20}$ ), Punthamara (Mathews 1905, p. 51), Galali (Mathews 1905, p. 51)

- two of the three Yarli languages: Malyangapa (Elkin 1931, p. 53) and Wadigali (Elkin 1931, p. 53).

Hercus and Austin (2004) noted that people of these two languages shared ceremonies with Wangkumara people and Wadigali also with the Yandruwandha, whereas Yardliyawara people, who spoke the third Yarli language, had ceremonial links with their Adnyamathanha neighbours to the west. We note also that the Central Karnic languages are divided by their moiety terms between the South Australian set, south-west Queensland set and Cooper Creek set. Only the Eastern Karnic group of languages shows consistency with respect to their social category terms. ${ }^{21}$ The Karnic languages with Kulpurru and Thiniwa moiety names can be seen in Figure 18.

16 See Chapter 8 for a possible etymological connection between Kulparru and the General Queensland section term Kuparu.

17 In fact, Mathews used shared moiety or section names as the basis for his recognition of so-called nations.

18 The most authoritative spelling is now Pilardapa (e.g. Breen 2004a, p. xvii).

19 See Bowern (2009) on this classification: the status of Galali has been disputed. There has been some doubt about the identification of Punthamara and Galali.

20 Based largely on material elicited by Gavan Breen; names are spelled Kulpurra and Thiniwa.

21 Wafer and Lissarrague (2008, p. 458) mentioned that in one of his publications, Mathews included Punthamara among the groups that have the most widespread Queensland system of sections. 


\section{The South-West Queensland Set}

The Karnic languages located north of the Queensland - South Australia border have a different set of moiety names. For Pitta-Pitta and closely related dialects, Roth (1984 [1897], p. 56) gave the matrimoiety names Ootaroo and Pakoota. The first of these is recognisable as the widespread Queensland term Wuthurru. We normalise the second name as Parrkatha, following Breen's (1981b, p. 130) phonemicisation of the term in Mayi languages, in spite of Roth's spelling with $o o$ in the second syllable for PittaPitta (versus his spelling of $p \hat{a}-k \breve{u} t-t a ̆$ for other languages). Other languages to the north-east share these names, including Guwa, Wunamura, MayiYapi, Mayi-Thakurti and, apparently, Yanda, which Roth (1984 [1897], p. 40) included (as his Yunda) in the Boulia district as a messmate of Pitta-Pitta. To the north, Kalkatungu shares Ootaroo but has Malara in place of Parrkatha; Yalarnnga, between Kalkatungu and Pitta-Pitta, has the moiety name Wutharru - the other name, possibly Malyarra, cannot be confirmed (Breen \& Blake 2007, p. 101). This set of moiety terms exists in a system that also contains four section names. ${ }^{22}$

Among the Northern Karnic languages, we can assume that the same moiety names are also found in Wangka-Yutjuru, which was spoken west of Pitta-Pitta, since Roth (1984 [1897], p. 56) gave $\breve{u}$-tă-roo and bǔr-gǔt-tă as class names among the Roxburgh (Georgina River) blacks. A comparison of Roth's map (1984 [1897], Plate 1) with that of Blake and Breen (1971, before p. 1) places this in Wangka-Yutjuru territory. Elkin (1931, p. 53) reported the Pitta-Pitta moiety names (Wuturu and Parkata in his spelling) for three further Karnic languages: Ngulupulu (a dialect of Pitta-Pitta according to Blake 1979, p. 184); Yelyuyendi (Yarluyandi); ${ }^{23}$ and Marula (Marulta), an alternative name for Mithaka, with which it was a co-dialect (Breen 1971, p. 9). Howitt (1996 [1904], p. 192) had earlier reported the moiety names Wuturu and Parkata for Ngulubulu, Yelyuyendi and Marula, plus a further Karnic language Karangura (see Hercus 1991). For Karuwali, which is another alternative name for Marulta/Mithaka, Elkin gave moiety names Wuturu and Malura; the latter appears to be

22 For the Pitta-Pitta, these are Kupuru and Wunku (belonging to the Wuthurru moiety), and Kurrkila and Panpari (belonging to the Parrkatha moiety). These section names are shared over a great area of central Queensland (see Chapter 8).

23 From 1965 onward, Luise Hercus found that families of mixed Yarluyandi-Wangkangurru descent were using the Wangkangurru moiety names Matharri and Kararrhu. The most authoritative spelling is now Yaluyandi (e.g. Breen 2004a, p. xvii). 
the same term as Malara, reported by Roth for Kalkatungu. ${ }^{24}$ Elkin did not report section terms for these four Karnic languages. Therefore, we might surmise that in the Northern Karnic languages, the section system is a recent innovation overlaid on an older moiety system. In Figure 18, the Karnic languages with moiety names Parrkatha and Wuthurru can be compared to all languages with Parrkatha and Wuthurru. According to Elkin's field notes (seen by Hercus), the Parrkatha and Wuthurru moieties are pragmatically equivalent to Kulparru and Thiniwa respectively of the Cooper Basin. ${ }^{25}$

\section{The Darling River Set}

\section{The Makwara and Kilparra Set}

This had been called the 'Paakantyi system' by Wafer and Lissarrague (2008, p. 420), who spelled the moiety names Makwara and Kilparra. Earlier Mathews had called this the 'Barkunjee nation' with the terms Keelparra and Mukwarra (see subsection 'Earlier Mapping of Moieties'). Howitt (1996 [1904], p. 97) referred to peoples with the 'class names ... Kilpara and Mukwara' as one of the 'great groups of tribes, having the two-class system'. He included a large number of tribal names, including the 'Itchumundi nation', encompassing the Wilya, Kongait, Bulali and Tongaranka tribes; and the 'Karamundi nation', consisting of the Milpulko, Naualko, Guerno and Barrumbinya tribes, as well as the Barkinji tribe and the Wiimbaio tribe; the latter is an alternative name for the Marawara dialect of Paakantyi. Further peoples mentioned by Elkin (1931, p. 53) as using the Makwara and Kilpara terms are the Bolali [Bulali], Wilyali and Wilyakali (the last two are alternative versions of the same name). All of these named groups, except the Barrumbinya [Barranbinya], involve people who spoke the Paakantyi language in contemporary terms (Hercus 1982, 1993). ${ }^{26}$

24 Breen (1981b, p. 130) gave maLaRa for the Mayi language Ngawun (where $L$ and $R$ represent uncertainty regarding the exact form).

25 We don't know what to make of this comment from Elkin's field notes: 'Police tracker at Birdsville says tribe north of Yelyuyandi = "Mulubulu". The moieties = "Yepari" (= Kararu) \& Yêta (= Matari)'. Yelyuyandi and Mulubulu are presumably Yarluyandi and Ngulupulu respectively.

26 Hercus $(1982$, p. 6) mentioned that the Paakantyi shared the section system with their eastern Wangaaypuwan neighbours, and cited Berndt (1964), who suggested that the sections were 'possibly introduced' (cf. Berndt \& Berndt 1981, p. 56)—which we take to refer to a recent adoption. 
For Barrumbinya, see Oates (1988a), who called the language Barranbinya, but provided no information on moiety names. Barranbinya is a separate language, perhaps most closely related to Muruwari (on the Culgoa River), which has a four-section system like that of the Central New South Wales languages (Oates 1988b).

As for the southern regions where these moiety names were used, Howitt (1996 [1904], p. 100) stated: 'Tribes having these class names extended up the Murray River as far as the Loddon'. According to his map, these include his Kerinma, Leitchi-Leitchi, Weki-Weki, Wathi-Wathi and BuraBura. This apparently includes languages classified in the Lower Murray subgroup (see Horgen 2004)-Kureinji (also known as Kerinma and Keramin and including Yari-Yari), Yitha Yitha, Dadi Dadi (also called Tharti-Tharti) ${ }^{27}$ and Yuyu (Wafer \& Lissarrague 2008, p. 420) ${ }^{28}$ - as well as dialects of the north-west Kulin language: Madhi Madhi, Wadi Wadi, Weki-Weki and Ladji Ladji or Letyi-Letyi (Blake et al. 2011, p. 25). ${ }^{29}$ Radcliffe-Brown (1918, pp. 249-50) confirmed the presence of the matrimoieties Kailpara and Mäkwara (in his spelling) among the Ladji Ladji (his Laitu-laitu) and Dadi Dadi (his Tạti-tatiti).

This set thus overlaps with the whole area of the large Paakantyi language, but also includes the Barranbinya language on its northern fringe, plus some languages of the Lower Murray group, and a small section of the Kulin languages. Figure 19 shows the distribution of the Makwara and Kilparra terms, the Paakantyi language area, the distribution of the Lower Murray group of languages and the subset of these languages that have the Makwara and Kilparra moiety names.

27 This is confirmed by Barwick's (1998, p. 76) account of the novelty of the marriage of the Woiwurrung elder Barak to Annie (Ragun), from near Euston on the Murray River, since it involved a union between people with patrilineal and matrilineal systems. A. L. P. Cameron is quoted (in Howitt 1883, p. 506) as remarking on the ability of the Wadi Wadi to relate their MukwaraKilpara system to the four-section 'Kamilaroi' system of their eastern neighbours.

28 Horgen (2004, p. 305) quoted moiety names Kelpara and Mokkara from Tindale.

29 The most authoritative indication of the relative location of these groups is the map in Clark and Ryan (2009, p. 77). 


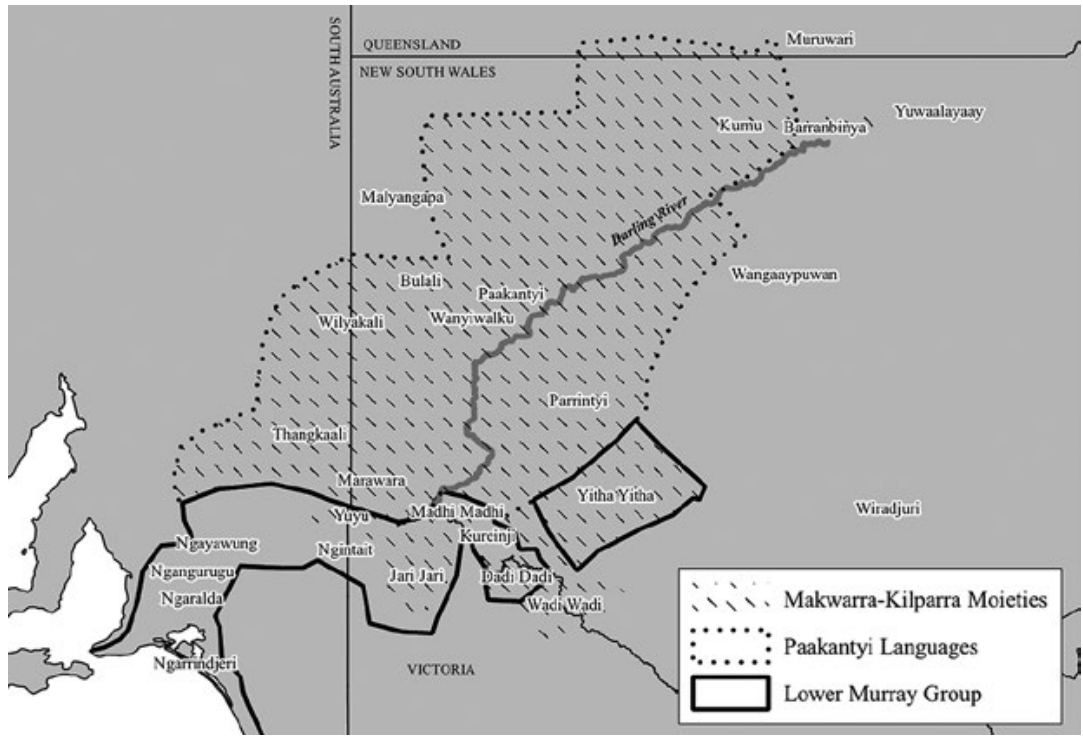

Figure 19: Makwarra-Kilparra moieties; Paakantyi and Lower Murray languages.

Source: Authors' work.

Some of the earliest available references to this set imply that the moiety names have meanings apart from their reference to social categories. Reverend John Bulmer is quoted by Smyth (1878, p. 86) as follows:

The blacks of the Murray are divided into two classes, the Mak-quarra or eagle, and the Kil-parra or crow. If the man be Mak-quarra, the woman must be Kil-parra. A Mak-quarra could not marry a Mak-quarra nor a Kil-parra a Kil-parra. The children take their caste from the mother, and not from the father.

Fison and Howitt (1880, p. 288) quoted a similar statement from the same man: 'The Wa-imbio [tribe, speaking the Marawara dialect of Paakantyi] are divided into two primary classes, Muquarra (eaglehawk) and Kilparra (crow)'. However, these names are not the ordinary words for 'eaglehawk' and 'crow' respectively, since, according to the Paakantyi dictionary (Hercus 1993), the words for 'eaglehawk' are pilyara or warriku (in the Kurnu dialect) and 'crow' is waaku. Hence, the claim about the meanings of the moiety names being eaglehawk and crow may rather indicate that the two birds were emblematic of the two moieties. ${ }^{30}$

30 Cf. Fison and Howitt's (1880, p. 40) information that for the Mackay area, according to Bridgman: 'The symbol of the Yoongaroo division [i.e. moiety] ... is the alligator, and of the Wootaroo the kangaroo'. 
Radcliffe-Brown (1918, p. 249) was told by his Ladji Ladji informant that 'there was a special connection between Kailpara and the emu [note: not the crow] and a similar connection between Mäkwara and the eaglehawk'. The nature of this 'special connection' is not further indicated.

Another possible explanation has been proposed by Wafer and Lissarrague (2008, p. 420):

In language groups that use the Paakantyi-type moiety system, evidence from a number of groups indicates that the Eaglehawk totem is classed as Makwara (Howitt 1904, pp. 98-100); and, in the one case where Crow is listed as a totem, it is classed as Kilparra (Howitt 1904, p. 100). Thus, it seems fairly clear that the moiety systems of the Darling-lower Murray (Paakantyi-type) and the upper Murray [our Central Victorian system; see subsection 'The Bunjil-Waang Set'] are equated with each other.

However, such social equivalence is not strictly possible, since the eaglehawk-crow system of Central Victoria involves patrilineal moieties, whereas the names of the Darling set denote matrimoieties. Thus, persons classified in the Darling system as 'eaglehawk' share this identity with their mother, while their father must be 'crow'; conversely, in the Central Victorian system, this person's father is also 'eaglehawk', while their mother is 'crow'. Since the two systems only partially overlap, an explanation in terms of the equivalence between different social systems is not tenable.

For the patrilineal eaglehawk and crow system of Central Victoria, see subsection 'The Bunjil-Waang Set'. See also the (somewhat different) matrilineal eaglehawk and crow system of the Alpine languages, described in the section 'The Alpine Area with "Eaglehawk" and "Crow" Moieties'.

\section{Other Two-Term Terminology Sets}

Another set of binary classification names is found around the Darling River area—among Paakantyi-speaking peoples, as well as the Malyangapa (of the Yarli linguistic subgroup) to their west and, to their east, the (Ngiyampaa-speaking) Wangaaypuwan and Wiradjuri (of the Central New South Wales linguistic subgroup). The latter two otherwise have a system of four sections that group into two matrimoieties. It is not clear how these alternative names are related, in their meaning and usage, to the standard set of moiety terms. However, we attempt to show below how they may be formally related to one another and the standard terms Makwara and Kilparra. 
Howitt (1996 [1904], p. 106) said of the 'tribes of the Itchumundi nation' (i.e. western Pakantyi) that the names Mukolo and Ngielpuru 'accompany the class names Mukwara and Kilpara'. This wording suggests that these are alternative names for the same moiety divisions. The former name recurs among some of the Wiradjuri, who have a system of four sections and whose language belongs to the Central New South Wales subgroup. Howitt (1996 [1904], p. 107) stated that in the Wiradjuri country near Mossgiel, north of the Lachlan River, in addition to the four section names, there are class (i.e. moiety) names Mukula (including the Ipai and Kumbo sections) and Budthurung ${ }^{31}$ (including the Murri and Kubbi sections). For the Wongaibon [Wangaaypuwan], north of the Wiradjuri of the Lachlan River, he reported the existence of four sections plus the (matri-)moiety names Mukumurra (for the Murri and Kubbi sections) and Ngielbumurra (for the Ipai and Kumbo sections) (Howitt 1996 [1904], p. 108). Howitt's information on Wangaaypuwan can be compared to that of a later source, Radcliffe-Brown (1923, p. 424), who rendered the moiety names as Mákayära (or Mákwayära) and Kilpuyära, attributing his and Howitt's differences between the forms of names to probable 'local differences of dialect'. This does not appear to be an adequate explanation of the facts. Radcliffe-Brown's Wangaaypuwan moiety names match closely the moiety names Magungera and Dilbungera indicated by Beckett (1967, p. 456) for the Malyangapa to the west of the Paakantyi. ${ }^{32}$ To complicate matters further, for the Yuwaalayaay, northern neighbours of the Wangaaypuwan, who also have a system of four section names, the Gamilaraay, Yuwaalaraay, and Yuwaalayaay dictionary (Ash et al. 2003, p. 106) reports a social group term Magula (that is Makula in our spelling system) that contrasts with Bumbira. ${ }^{33}$ The terms Magula and Bumbira are also found further north in the Queensland language Bidjara, which also has the moiety names Wudhurru and Yangurru (Breen 1981a, p. 281).

An analysis of the forms of moiety names in Paakantyi and its neighbours is presented in Table 15 (asterisks represent reconstructed forms). Note that there is evidence for forms with different vowels, such as *mukuand *maku-. Howitt's forms suggested a phonemic form Mukulu for Itchumundi and Wiradjuri and Mukumarra for Wangaaypuwan for one name, and, for the other, Ngilpurru for both Itchumundi and

31 This term is also given as the name of a totem: 'black duck'.

32 Note that the Cooper Basin terms Kulparru and Thiniwa were earlier reported for the Malyangapa by Elkin (see section 'The Cooper Basin Set').

33 This information was gained by Ian Sim in the 1950s (John Giacon, pers. comm.). 
Wangaaypuwan. In both cases, we have a common stem, $M u k u$ - versus Ngilpu-, followed by a different suffix, -marra in Wangaaypuwan and -lu or -rru (one of which may have been misheard) in Itchumundi. RadcliffeBrown's and Beckett's names seem to indicate a suffix -ngarra (or perhaps -ngirra) added to roots maku- and kilpu-, with the standard Paakantyi forms having an alternative suffix of -warra in Makuwarra and -arra in Kilparra, which was perhaps reduced from an earlier *Kilpuwarra. One should perhaps assume that the forms with -ngarra also once occurred in Pakantyi and were borrowed by their neighbours to both the west and the east, with Malyangapa further adapting the word-initial $k i$ - of Kilparra as thi, hence, Thilpangarra. Such an adaptation is plausible in the light of the fact that there are no examples of the word-initial $k i$ or tyi-in Malyangapa, but plenty of instances of thi-, according to the wordlist in Hercus and Austin (2004, pp. 647-54). Interchanges between $k i$ and tyi are common in Australian languages, and thi is the sequence most similar to tyi. Therefore, if a word beginning with $k i$ - was to be borrowed into a language that lacked initial $k i$ - and tyi-, thi-would be the most obvious replacement. However, there is no clear explanation for the difference between the forms *ngilpu- and *kilpu-, although unexplained interchanges between stops and nasal are known to occur in Australian languages. In summary, these diverse forms used with the moieties seem to be connected historically through a combination of borrowing and adaptation to the resources of the particular languages.

Table 15: Analysis of moiety names in Paakantyi and neighbouring languages.

\begin{tabular}{|l|l|l|l|}
\hline Language & & & Suffix \\
\hline Itchumundi (Howitt) & Mukolo & Ngielpuru & -lu/-rru \\
\hline Wiradjuri (Howitt) & Mukula & & -la \\
\hline Wangaaypuwan (Howitt) & Mukumurra & Ngielbumurra & -marra \\
\hline & *muku- & *ngilpu- & \\
\hline Paakantyi & Makuwarra & Kilparra & -arra \\
\hline Wangaaypuwan (Radcliffe-Brown) & Mákwanära & Kílpunära & -ngarra \\
\hline Malyangapa (Beckett) & Magungera & Dillbungera & -ngarra \\
\hline Yuwaalayaay (Sim) & Magula & & -la \\
\hline & ${ }^{*}$ maku- & *kilpu- & \\
\hline
\end{tabular}

Source: Authors' work. 
A possible etymology of one of these names can be suggested. A wordlist by Reay (1945, p. 4) gives Gilpara 'cold wind, east wind' and Makwahra 'rain wind, west wind'. The Paakantyi dictionary does not give a term for cold wind, but it does give a term from the Paaruntyi dialect for 'cold weather', which is makura (Hercus 1993, p. 38)-makurra in our standardised orthography. This looks like a derivative of the stem *makuthat we have identified for one of the moiety names. Unfortunately, it is the wrong term, since it was Kilparra that was supposedly named from the cold wind. However, this may still reflect the actual etymology if the referents somehow got switched in (their relaying of) Hero Black's explanation in Reay (1945). ${ }^{34}$

\section{The Central Victorian Set}

\section{The Bunjil-Waang Set}

In a large region of central Victoria, there is a moiety system characterised by the names Bunjil (Puntyil in our orthography) and Waang (Waa in some languages), which mean 'eaglehawk' and 'crow' respectively. Howitt (1996 [1904], pp. 126-7) described this population as the 'Kulin nation', after kulin 'man' in most the languages (Howitt 1996 [1904], p. 70). Mathews (1898, p. 326) called this system that of the 'Bangarang nation', using a term for [Yorta Yorta speaking] northern groups that was employed by Curr (Furphy 2013). In a rare departure from the norm in south-eastern Australia, these moieties are patrilineal, with the names being inherited from one's father rather than the mother. This claim of Howitt's has been confirmed by later research by Barwick (1984).

Many of the languages with this terminological set belong to the Kulin subgroup and within Kulin to both the east and the West Kulin subsubgroups. First, there is what Blake (1991) called the Central Victoria language, which is the sole member of the East Kulin subgroup. A second language is the adjacent Wathawurrung, which belongs to the West Kulin subgroup. A third language is most of the Djadjawurrung, the easternmost dialect of the vast Western Victoria language, which also belongs to West Kulin (Blake \& Reid 1998, p. 5). However, the westernmost clan of the

34 It may be relevant that a hot and cold wind division existed among the Malyangapa, in addition to the regular moiety names (Beckett 1967, p. 457) also in Andyamathanha, and that wind meanings also occurred for generation moieties in the Western Desert (Patrick McConvell, pers. comm.). 
Djadjawurrung, Larning Gundidj (Clark's clan 9) according to Clark (1990, p. 162), used the name Gamadj, a term that belongs to the Western Victorian set (see section 'The Western Victorian Set').

The accuracy of the moiety names being the names of the eaglehawk and crow is confirmed by linguists: Blake (1991, p. 87) for the Central Victoria language (also called Woiwurrung after one of its dialects) gave bundjil 'eaglehawk' and waang 'crow'; and Blake et al. (1998, pp. 105, 102) for Wathawurrung gave bundjil as one of the words for 'eagle' (original spelling boondyill) and waa as 'crow'. Howitt (1996 [1904], p. 126) reported that among the Djadjawurrung the name Bunjil is replaced by Wrepil, which is their term for 'eaglehawk'. The terms werpil 'eagle' and waa 'crow' are confirmed by Blake's (2011) consolidated account of the Djadjawurrung language. 'Eaglehawk' is also werpil elsewhere in the Western Kulin megalanguage-for example, in Wergaia (Hercus 1986, p. 212) and Wadi Wadi (Blake et al. 2011, p. 248).

While the Djadjawurrung, who were linguistically Kulin, 'calqued' one of the moiety names - translating it into their equivalent term-another group used a different strategy. The Bangerang people, which Howitt reported as using the Bunjil and Waang moiety names, were speakers of the Yorta Yorta language. In this language, according to Bowe and Morey (1999), 'eagle' is gurranyin or wanmirr and 'crow' is dangamai or wakirr. We conclude that in Yorta Yorta, moiety names have probably been borrowed from Kulin languages, where they presumably originated. Yorta Yorta does not belong to the Kulin subgroup (eastern or western), but is related closely only to its neighbour Jabulajabula, their Yabula Yabula (Bowe \& Morey 1999, pp. 133-6, 275).

One further language shares these moiety names. According to Barwick's (1984, p. 118) clan map, two clans of the Pallanganmiddang [Waywurru] that adjoin the Taungurung (of the Central Victoria language) - the Yowung-illam-balluk around Mount Buffalo and the Warrarakballuk around Wangaratta—are classified as Bunjil and waa respectively. Barwick (1984, p. 104) quoted Howitt's papers that included in his Kulin nation 'two clans northeast of the Kulin cultural bloc whose speech was utterly different but who had intermarried with Kulin neighbours since precontact times'. In this language, ${ }^{35}$ 'eaglehawk' is warrimu and 'crow' is berrontha (Blake \& Reid 1999, pp. 24-5). Thus, it appears that (perhaps 
just part of) the Pallanganmiddang [Waywurru] had adopted the Kulin patrimoiety system along with its names, without translating them into their own language, as the Yorta Yorta had also done. Howitt's information suggested that intermarriage with members of the Central Victoria language group was a mechanism for spreading the moiety names into other languages. As for Howitt's comment that their speech was 'utterly different' from that of the Kulin, this is confirmed by modern linguistic research: the Pallanganmiddang/Waywurru language is not closely related to any other language (Blake \& Reid 1998, p. 3).

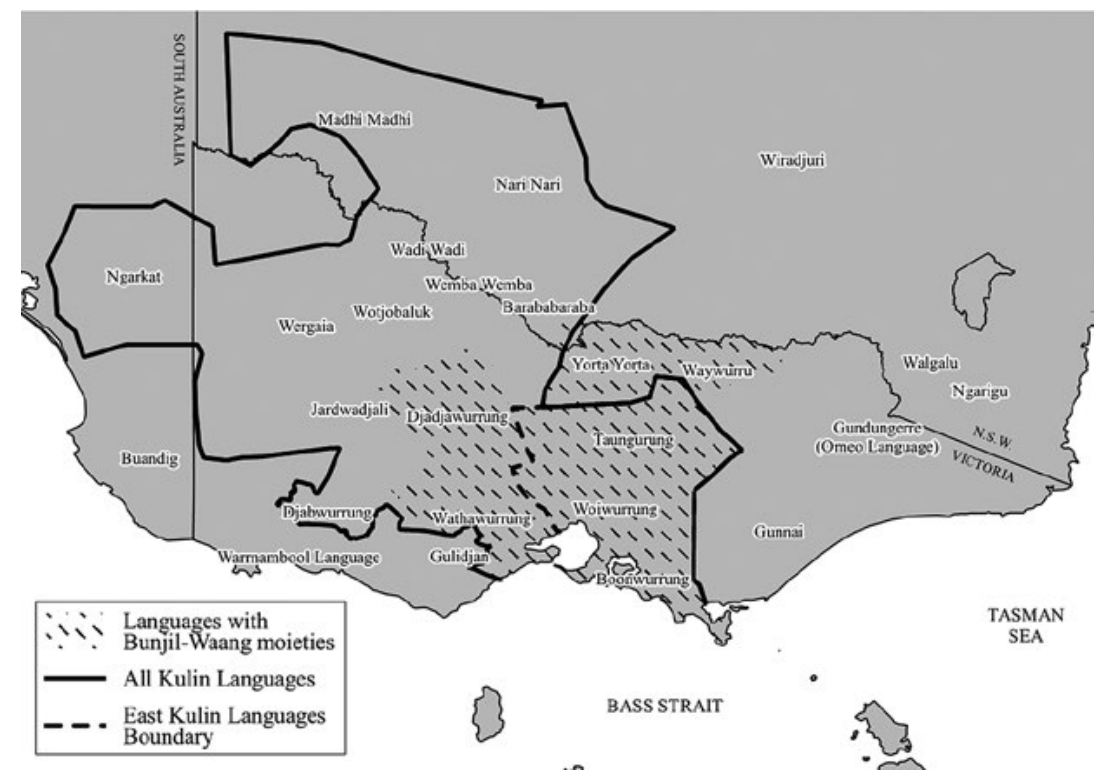

Figure 20: Bunjil-Waang moieties and Kulin languages.

Source: Authors' work.

The relationship between the Bunjil-Waang naming set and the Kulin languages is shown in Figure 20. This map shows the distribution of the Bunjil-Waang set, the extent of the East Kulin language, the furthest extent of all the Kulin languages, ${ }^{36}$ as well as surrounding languages that are mentioned in this chapter. The linguistic classification is based on Blake and Reid (1998). Our interpretation of the historical relations between this moiety terminological set and the language groupings yields the following scenario. The moiety system (at least with this set of terms)

36 Note that Dadi Dadi, a non-Kulin language, is located within these boundaries (see Figure 19). 
is probably later than Proto-Kulin, the ancestor of all the Kulin languages, since the terms are missing from much of West Kulin. It may go back as far as Proto-East Kulin, the relatively undifferentiated ancestor of the central Victoria dialects. Subsequently, the terminological set spread to the adjacent Kulin languages to the west, as well as to the Yorta Yorta in the north-west and to adjacent clans of the Pallinganmiddang/Waywurru to the north-east. While the Djadjawurrung translated the Bunjil terms into their own language, the two northern groups did not substitute their own words but simply adopted the Kulin terms along with their functions of the patrimoiety system.

\section{The Alpine Area with 'Eaglehawk' and 'Crow' Moieties}

Howitt suggested that the 'eaglehawk' and 'crow' moieties extended even further east. Howitt (1883, p. 506) ascribed it to 'the Wolgal [Walgalu] tribe, which once inhabited the upper waters of the Hume [i.e. Murray], the Murrumbidjee [Murrumbidgee], and the Tumut rivers'. He also attributed the system to the people of the 'upper waters of the Murray, Murrumbidgee, Snowy, and Tambo Rivers, the Ya-itma-thang, Ngarigo, and Wolgal' (Howitt 1996 [1904], p. 101). These are probably all speakers of dialects of the same language, belonging to the Yuin subgroup of south-eastern New South Wales, known as Walgalu in the Tumut region, Ngarigu in the Monaro area and the Omeo language in Victoria (Koch 2012, p. 140; Wafer \& Lissarrague 2008, pp. 106-7): the AIATSIS reference name of this Omeo language is Gundungerre. Here, the moiety names are not the Kulin Bunjil and Waang, but native names Malian 'eaglehawk' and Umbe 'crow' in Walgalu, and Merung 'eaglehawk' and Yukembruk 'crow' in Ngarigu (Howitt 1996 [1904], p. 102). In these languages, there are a number of totems (Howitt lists six to nine for each) subsumed under each of the moiety divisions; these include 'bat' (Walgalu Nadjanajan and Ngarigu Nadjatajan) under eaglehawk and 'rabbit-rat' Tchuteba (in both Walgalu and Ngarigu) under crow. ${ }^{37}$ As for the Omeo language, Howitt (1996 [1904], p. 101) stated that the Ya-itma-thang who intermarried with the Ngarigu had among their totems the same

37 This bat division is not to be confused with the widespread use (in south-eastern Australia) of the bat as a sex totem for men (see Howitt 1996 [1904], pp. 148-51; Wafer \& Lissarrague 2008, pp. 445-7). 
Tchuteba 'rabbit-rat' and Nadjatejan 'bat', and that these were on opposite sides of the tribe, as manifested in their ball games, in which teams were presumably formed on the basis of moiety membership. ${ }^{38}$

The interpretation of these facts is not clear. One possibility is that the Omeo people had the same system as the Ngarigu and the Walgalu. Another possibility is that they had similar groups of totems, but did not use the overarching eaglehawk and crow names. A possible historical scenario for the Alpine region is that at some point in time, Walgalu and Ngarigu (and perhaps the Omeo people) adopted the Kulin organisation of two moieties headed by eaglehawk and crow and used their own terms rather than borrowing the Kulin names. However, an important difference among the Alpine tribes was that their eaglehawk and crow moieties were matrilineal (Howitt 1996 [1904], p. 197). This fact suggests that their interaction with the Eastern Kulin was much less direct than that of the immediate neighbours of the Eastern Kulin (the Yorta Yorta and Pallanganmiddang/Waywurru), and that they simply borrowed an idea of social organisation, with some of its terminology, and grafted it onto their own system of totems.

One further group that may have had a similar eaglehawk and crow terminology is the Bidawal (also called Bidwell or Birrdhawal) of the south-eastern corner of Victoria. Their language is closely related to the Gunnai of Gippsland. Howitt (1996 [1904], p. 103) mentioned one family of Biduelli (as he called them) with the Ngarigu class name Yukembruk 'crow' and a totem Tchuteba 'rabbit-rat'-this looks like the Ngarigu system. He noted that another family had the name Bunjil, 'apparently connecting the Biduelli with the Mogullum-bitch, a Kulin tribe on Upper Ovens River [in Victoria]'. These names may only have applied to particular families who intermarried with peoples who used the moiety system: the first family involved a man who lived in the Monaro tableland, whose wife was Ngarigu and whose mother was from the Omeo district (Howitt 1996 [1904], p. 80). The fact that individual families not only knew but also used their neighbours' moiety terminology suggests one plausible mechanism by which such a system could have spread from one group to the next. ${ }^{39}$

38 Elkin (1964, p. 123) commented that, where ball games were played by moieties, these were part of a ceremonial program, where the facts are better known. This indicates the role of moieties in ceremony.

39 We thank Patrick McConvell for the idea of this as a mechanism of diffusion, and Ted Ryan for the idea that people typically knew their neighbours' system. 


\section{The Western Victorian Set}

The group with this terminology set was given the label 'Booandik nation' by Mathews (1898, pp. 331-3). The most recent source of data is given by Clark (1990). The matrimoiety names were Kamaty or Kapaty ${ }^{40}$ and Kurukity, with feminine versions that took the suffix -kurrk (from kurrk 'woman'): spelled for instance as Kamatchgurk and Krokitchgurk. Mathews (1898, p. 333) was told, by Paakantyi people from Balranald, that Gamadj and Grugidj were pragmatically equivalent to the Muckwarra and Keelparra of the Paakantyi. This Western Victorian system obtained among several named groups of speakers of the (West Kulin) 'Western Victoria' megalanguage (of Blake \& Reid 1998, p. 4), including Wemba Wemba ${ }^{41}$ the Wergaia (called Wotjobaluk in Howitt 1996 [1904], p. 120), Jardwadjali and Djabwurrung. Clark (1990, pp. 91, 237) gave glosses for the moiety names among the Jardwadjali and Djabwurrung: Gamadj is said to mean 'black cockatoo' and Grugidj 'white cockatoo'. ${ }^{42}$ Among the latter two, Gamadj [Kamaty] has an alternative form Kaputj [Kapaty]. Consideration of all the sources suggests that the black bird is the Banksian or red-tailed black cockatoo, and the white bird is the longbilled corella.

A similar set of terms is found among what we might call the Bunganditjan languages: Buandig (also known as Bunganditj), the Warnambool language, and Gulidjan, the Colac language. ${ }^{43}$ Fison and Howitt (1880, p. 33) gave the class names of the Mount Gambier (South Australia) tribe [the Bunganditj] as Kumite and Kroki, with feminine forms Kumitegor and Krokigor. Blake's (2003a, p. 128) Bunganditj grammar gave kurukitj as 'corella'. The speakers of the Warrnambool language,

40 The relation between forms with $m$ versus $p$ is not explained. It is not a regular correspondence between the languages. According to Ted Ryan (pers. comm. 13 November 2016), the Kapaty variant may have been used only by people south of the Grampians.

41 Mathews described the group as natives of the Avoca River (1898, p. 333); Mathews also called them Wambawamba (1903, p. 184). Howitt (1996 [1904], p. 138) stated that west of the Avoca River, the Krokitch-Gamutch system was used, in contrast to the Bunjil-Waang system of the Djadjawurrung east of the river.

42 Apart from the exact species of bird that is intended, there is the question of whether these terms are the names of birds in each of the relevant languages or only names of social categories whose emblems are the respective birds.

43 The genetic relationship between Buandig and the Warrnambool language is not certain, and the affiliation of the Colac language is even more doubtful, according to Blake and Reid (1998, pp. 9-12). We nevertheless tentatively group the first two together as a Bunganditjan subgroup. For the location of these languages and those mentioned in the preceding paragraph, see Figure 20. 
called the Gournditch-Mara by Howitt (1996 [1904], p. 124), had the names Kaputch and Krokitch, the feminine form adding the suffix -yarr. ${ }^{44}$ Each class name had an associated totem and a number of associated sub-totems; Kaputch was associated with black cockatoo and Krokitch with white cockatoo (Howitt 1996 [1904], p. 124). The glosses can be refined somewhat by the information in Blake's (2003b, pp. 185, 190) Warrnambool grammar, which gave kapatj as 'cockatoo, red-tail, black' and kurukitj as 'long-billed cockatoo'. Their eastern neighbours, the Gulidjan, likewise had the moiety names Gabadj (Black Cockatoo) and Guragidj (White Cockatoo) (Clark 1990, p. 222).

The eastern part of the Warrnambool language area seems to have had a pre-moiety system of matri-totems. Howitt (1996 [1904], p. 125) reported that for the natives near Mortlake, Cameron found no class (i.e. moiety) names but four totems: Krokage 'white cockatoo, red crest', Kubitch 'black cockatoo', Karperap 'pelican' and Kartuk 'whip snake'. These totems are paired such that 'Karperap is supplementary to Krokage, and Kartuk to Kubitch. Krokage may marry either Kubitch or Kartuk, and Kubitch may marry either Krokage or Karperap, and the children belong to the mother's totem' (Howitt 1996 [1904], p. 125). For the (same) area east of the Gournditch-Mara, Dawson (1981 [1881], p. 26) explained the situation thus: 'Kuurokeetch and Kartpoerapp ... are so related, that they are looked upon as sister classes, and no marriage between them is permitted. It is the same between kappatch and kirtuuk; but as kuunamit is not so related, it can marry into any class but its own'. Dawson's wordlist (1981 [1881], p. li) glosses Kuurakeetch or Kuuruukeetch as 'cockatoo, long-billed' and kappatch as 'cockatoo, banksian'.

A possible historical scenario for the south-western Victorian region is that in a system in which totemic groups are ordered into two intermarrying sets (virtual moieties), one totem name could be treated as the lead or dominant totem and then be elevated to the status of a moiety name. As for the particular moiety names, it appears that kurukity (in our standardised orthography) is native to the Bunganditjan languages, since it occurs as a bird name in both Buandig and Warrnambool languages. From one or both of these languages, the term must have spread northward to the West Kulin languages, whose term for corella was katyakarr (see Dawson 1981 [1881], p. li for Djabwurrung; Hercus 1986,

44 We interpret the feminine suffix as -yarr rather than the -iyar posited by Blake (2003b). 
p. 252 for Djadjala [Wergaia] and Wemba Wemba; Hercus 1992b, p. 22 gave the Wemba Wemba and Wergaia forms as kathokarr and katyekarr respectively). The name kapaty was also given by Dawson as one of the dialectal terms for 'banksian cockatoo' in the Warrnambool language, from which it has apparently spread northward to Djabwurrung (Kulin). The alternative term kamaty is found in the remainder of the West Kulin dialects that have this terminology system and in Buandig; therefore, it could have originated in either of these two areas.

\section{The Distribution of Naming Sets}

In this section, we survey earlier attempts at mapping the moiety sets that we have discussed. We call attention to the finding that the nomenclature sets do not closely match the linguo-genetic classification of languages. We then provide our interpretation of what the distribution of terms reveals about the history of the systems.

\section{Earlier Mapping of Moieties}

Various scholars have attempted to map the distribution of moiety naming sets. Of these, the maps by R. H. Mathews and John Mathew come closest to ours, in giving the moiety names of their sets. However, none of these relate the distribution to language groups as currently understood, except for Dixon (2002, p. 17).

R. H. Mathews's (1898, p. 343) map of Victorian tribes shows his Bangarang, Booandik and Barkunjee (Paakantyi) 'nations', defined largely by their social category organisation. His map of South Australian divisions (Mathews 1900, p. 91) delineates, among others, his 'Parnkalla Nation', 'Yowerawarrika Nation', 'Barkunjee Nation' and the western part of his 'Booandik Nation'.

Howitt's (1996 [1904], facing p. 90) ${ }^{45}$ map of south-eastern Australia, reproduced here as Figure 21, indicates the approximate distribution of moiety, section and 'anomalous' class systems. The systems discussed in this paper are represented as 'two classes with female descent' (a large area of South Australia, the south-west corner of Queensland, the Darling River area, the middle Murray, and western Victoria plus south-eastern

45 Refer to pp. 832-3 in the 1996 reprint. 
South Australia), 'two classes with male descent' (central Victoria) and 'with anomalous class system and female descent' (an area of the far southwest of Victoria that includes the Warnambool area).

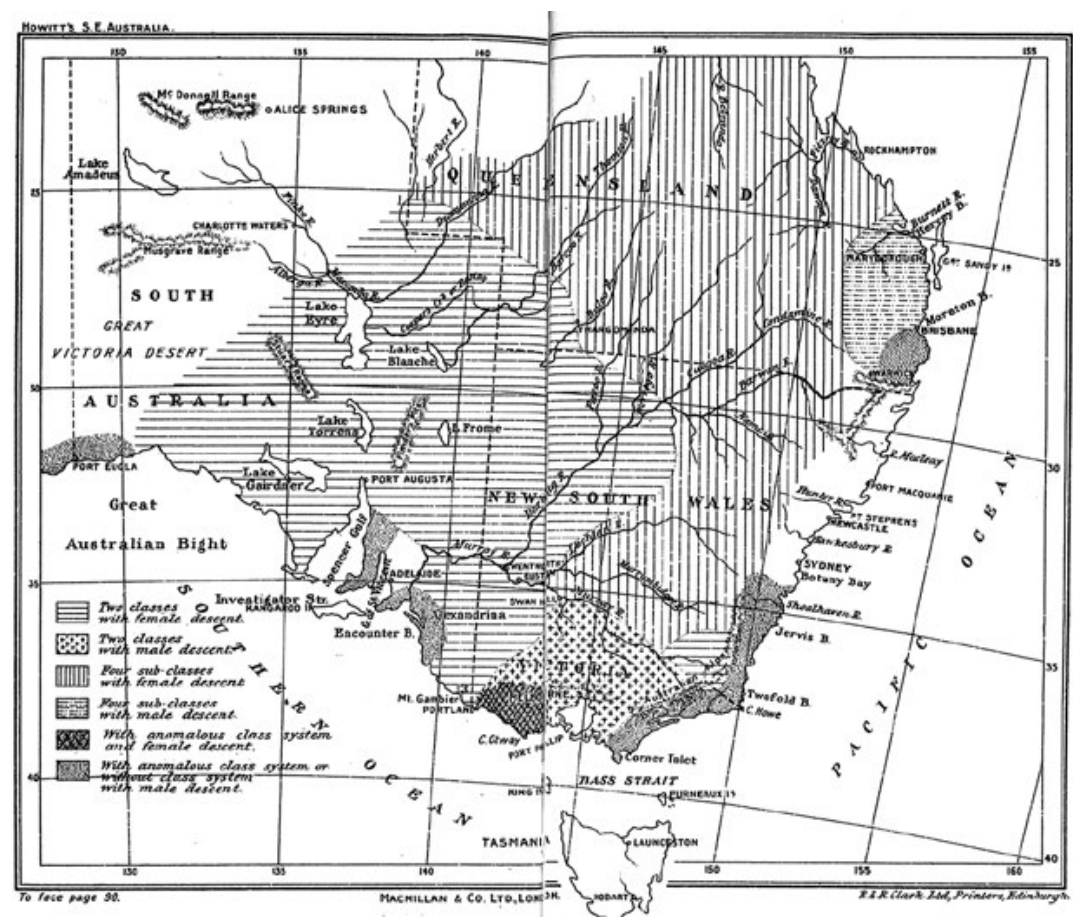

Figure 21: Howitt's 1904 map of south-eastern Australia.

Source: Howitt (1996 [1904]).

John Mathew's (1910, p. 164) map gives the distribution of social category names (his 'phratry names') over most of Queensland, New South Wales and Victoria-South Australia is rather empty. His map gives the Kilpara-Mŭkwara system around the Darling River, Kurokaitch-Kapaitch in western Victoria, the eaglehawk-crow system of central and eastern Victoria and adjacent parts of New South Wales, and the distribution of the names Pakoota and Wootaroo in Queensland.

Davidson's (1928, p. 92) map shows where moiety names are present in the whole continent-without any indication of whether these moieties are matrilineal or patrilineal or whether the moiety names coexist with section or subsection terms. 
Radcliffe-Brown's (1930-1, between p. 42 and p. 43) map shows the distribution of matrilineal and patrilineal moieties, sections, subsections, semi-moieties, paired sections and areas without moieties or sections. For south-eastern Australia, his map includes a large area involving eastern South Australia, western New South Wales and western Victoria that is marked with matrimoieties, a small area of central Victoria with patrimoieties and an even smaller area in the Alps with matrimoieties.

Berndt and Berndt (1981, p. 55) presented a map displaying 'distributional spread of Australian Aboriginal social organization'. The area we have discussed is included in their A zone, which manifests matrimoieties, with the qualification that sections have been (recently) introduced into Paakantyi; a B zone in central Victoria where patrimoieties are found; and a $\mathrm{D}^{1}$ zone in far south-western Queensland, where sections have spread.

Dixon's (2002, p. 17) map gives the approximate distribution of moieties, sections and subsections, and the absence of any of these, with admittedly some simplifications and extrapolations. The same map shows his (genetic and areal) classification of languages. One can note a certain degree of correlation of moieties with his linguistic groupings: WA (our Karnic and Yarli subgroups), WB and WC (our Thura-Yura subgroup), V (Paakantyi) and $\mathrm{T}$ (our Kulin and Bunganditjan subgroups).

\section{Mismatch of Naming Sets and Linguistic Subgroups}

We have documented a mismatch between the distribution of naming sets and that of linguistic subgroups. The results are described in this subsection and interpreted historically in the subsection 'Historical Interpretation of Distribution'. The relations between moiety names and linguo-genetic groups are displayed in Table 16, in which the moiety name sets are given in the columns and the linguistic groupings in the rows. A tick in a cell indicates that the naming set of the top row is manifested in languages of the linguo-genetic group listed in the first column.

Most of the Thura-Yura languages of South Australia have the Matharri and Kararrhu moiety names, but the moiety system is lacking in the southeastern part of this subgroup, Kaurna and Narungga. This naming set extends beyond Thura-Yura to include a number of Karnic languages, plus Yardliyawarra in the Yarli subgroup. The 'Cooper Basin set', with names Kulparru and Thiniwa, covers the languages of the presumed Eastern Karnic sub-subgroup, but also takes in some Central Karnic languages, plus Malyangapa (according to Elkin) and Wadigali of the Yarli subgroup. The 
'South-West Queensland set', with moiety names Parrkatha (or Malura) and Wuthurru, is used by speakers of both northern and Central Karnic languages, plus non-Karnic languages to the north (in conjunction with section names). The Darling River set includes the whole Paakantyi language area, plus Barranbinya to the north, and, to the south, several Lower Murray languages and dialects of the Madhi Madhi group of the Western Victoria (West Kulin) language. The Central Victorian set includes the whole of the Central Victoria (East Kulin) language, plus Wathawurrung and Djadjawurrung of the West Kulin sub-subgroup, plus the adjacent but unrelated Yorta Yorta and Pallanganmiddang/Waywurru languages. The Yuin languages in the Alpine area of New South Wales seem to have a related terminology set using their native terms for 'eaglehawk' and 'crow'. Finally, the Western Victorian set takes in most of the Bunganditjan subgroup (but some dialects of the Warrnambool language seem to have a pre-moiety system), as well as much of the West Kulin language area.

Table 16: Moiety naming sets versus linguistic genetic groups.

\begin{tabular}{|l|c|c|c|c|c|c|}
\hline & SA & Cooper & SWQId & Darling & CentVic & WVic \\
\hline Thura-Yura & $\checkmark$ & & & & & \\
\hline Karnic & $\checkmark$ & $\checkmark$ & $\checkmark$ & & & \\
\hline Yarli & $\checkmark$ & $\checkmark$ & & & & \\
\hline Paakantyi & & & & $\checkmark$ & & \\
\hline Lower Murray & & & & $\checkmark$ & & \\
\hline Kulin & & & & $\checkmark$ & $\checkmark$ & $\checkmark$ \\
\hline Bunganditjan & & & & & & $\checkmark$ \\
\hline Yotic & & & & & $\checkmark$ & \\
\hline Waveroo & & & & & $\checkmark$ & \\
\hline Yuin & & & & & $(\checkmark)$ & \\
\hline
\end{tabular}

Source: Authors' work.

This mismatch between linguo-genetic groups and social category naming sets has been forcibly noted by Blake et al. (2011, pp. 24-5). Their conclusions are worth quoting in some detail:

The people of the Mathi group, the neighbouring Murray River and the Paakantyi people to their west and north-west all had a matrilineal moiety system with the two moieties being called Kilpara and Makwara ...

This system ... was observed everywhere in Paakantyi country from Wentworth to Bourke and into South Australia ... 
The bulk of the Murray River people [our Lower Murray group] and the bulk of the Kulin people did not have this system, but the people in the far north-west of Victoria and adjacent parts of NSW share it: they formed a very special united group, although they belonged to three different types of languages, Murray River, Kulin and Paakantyi. In other words

Yitha-Yitha, Tharti-Tharti, Keramin (Kureinyi including also Yari-Yari) and Ngintait $(Y u y u)^{46}$ people all shared this Paakantyi system although the rest of the Murray River [our Lower Murray] language subgroup did not.

Mathi-Mathi, Letyi-Letyi, and Wati-Wati people all shared this Paakantyi system although other Kulin people, like for instance the neighbouring Wemba-Wemba, did not. (boldface in original)

Likewise, Wafer and Lissarrague (2008, p. 420 note 271) commented on Howitt's equating of the Bunjil ('eaglehawk') and Waang ('crow') moiety names with his 'Kulin nation':

Evidently this does not apply to the Kulin languages, mentioned above, that use the Kilparra-Makwarra moiety system. Nor does it apply to Perapa-Perapa ... which as Howitt himself points out (1904, p. 107), has a section system like that of the Wiradjuri. ${ }^{47}$

\section{Historical Interpretation of Distribution}

There are basically two scenarios that can result in the sharing of terms between languages (excluding chance): inheritance from a common ancestor language or acquisition through cultural contact. In the case of common inheritance, the explanation would be that the terms were present in the protolanguage before it diversified into separate dialects and sister languages and that the forms were simply transmitted from generation to generation. Language differentiation proceeds rather slowly, requiring perhaps 500 to 1,000 years for a language to diversify into separate languages-less for the development of distinct but mutually intelligible dialects. This explanation may be valid for two situations described here: Paakantyi and the Central Victorian language are both multi-dialect languages, whose common

46 We do not agree with the implied identity of Yuyu and Ngintait, and consider it doubtful that Ngintait had this moiety system. Regarding the Ngintait, Radcliffe-Brown (1918, pp. 247-8) reported: 'I have no exact information about the social organization, but I believe that the tribe had no dual division and was organized into local totemic clans in much the same way as the Nganuruku [Nganguruku] and Yaralde [Ngarrindjeri] tribes'.

47 We do not agree with Wafer and Lissarrague's inference that the very closely related Wemba Wemba also had the section system, since we have shown in the section 'The Western Victorian Set' that it had the Western Victorian set of moiety names. 
ancestors Proto-Paakantyi and Proto-East Kulin need not have been very remote in time-perhaps around 1,000 years. In contrast, the Thura-Yura linguo-genetic group is much more diverse, so its common ancestor is likely to have been considerably older. Also, not all of the languages classified as Thura-Yura share the Matharri-Kararrhu terminology: in fact, the south-eastern languages lack moiety terms altogether. If we were to posit that the names were inherited from Proto-Thura-Yura, we would have to assume that Kaurna and Narungga had lost the terms (as well as the moiety system) - a proposition that is otherwise unnecessary. We conclude that the terminology has spread subsequent to the differentiation of the ThuraYura languages (i.e. later than Proto-Thura-Yura ${ }^{48}$ ), since it is not found in the south-eastern languages of the subgroup. Turning again to the Kulin languages, if one were to project the Bunjil-Waang system back to the ProtoKulin stage, its presence in the West Kulin languages Wathawurrung and Djadjawurrung would be accounted for (by inheritance), but its absence in other West Kulin languages such as Madhi Madhi and Djabwurrung would be explained as a replacement by terms from the Darling or Bunganditjan system respectively.

The second explanation-acquisition through cultural contact—is clearly required to account for some of the shared terms. There are several mechanisms by which a language could have acquired its moiety names in a situation of cultural borrowing. The terms could simply be borrowed: this is clearly the case for Yorta Yorta and Waywurru (Pallanganmidhang), which have adopted the East Kulin terms Bunjil and Waang. Another kind of borrowing is called 'calquing' or 'loan translation'. Thus, Djadjawurrung has substituted its equivalent term for 'eaglehawk', Werpil. Native terms for 'eaglehawk' and 'crow' have similarly been used in the Alpine region. A third method of cultural borrowing is to adopt the principle of moiety names but supply terms with a different meaning - for example, terms for black and white cockatoo in place of eaglehawk and crow.

Since the distribution of moiety terminologies correlates so poorly with linguo-genetic groups, we conclude that, with the possible exception of Paakantyi and the East Kulin languages, the distribution of terms was formed more recently than the diversification of languages from protolanguages. Hence, the areas in which terms are shared are explained primarily by cultural spread or diffusion rather than by inheritance from common ancestral languages.

48 But occurring before the (regular) loss of initial $k$ in Adnyamathanha, since the term there is Ararrhu rather than Kararrhu. 
Blake et al. (2011, pp. 25-6) concluded that the matrimoiety terms Kilpara and Makwara spread from Paakantyi to some Murray River and Madhi Madhi (Kulin) groups in consequence of the fact that the speakers of these languages had come to form a sociocultural bloc.

\section{Direction of Spread}

This raises the question of where each set of terms has spread from. Two kinds of evidence can be invoked: the direction of spread points to a place of origin, and the etymology of the forms may conceivably suggest a particular language in which the terms originated. For the South Australian set (shown in Figure 17), we conclude, from the fact that the terms are missing from the south-eastern languages and that they are shared with some Karnic languages around the Lake Eyre basin, that the terms have most likely spread from the (north-)east. This puts their origin close to two other sets - those of the Cooper Basin and the Darling River. The Darling River set is adjacent to both the South Australian and Cooper Basin sets, and so might have influenced the development of both. ${ }^{49}$ Further, either or both of the South Australian and Cooper Basin terminological sets could have influenced the South-West Queensland set. The Darling River set was also either adjacent or relatively close, along the Murray River, to the two Victorian nomenclature systems. Moreover, this area is on the boundary between moiety names that are meaningful (the Victorian bird pairs) and without obvious meanings.

In fact, the area around the point at which the Darling and Murray rivers converge would be a good candidate for the locus of the spread of the moiety systems. This was an area of dense populations, involving a number of languages, including some that were not closely related. The people of different groups are reported to have participated in one another's ceremonies-which would have been facilitated by having equivalent moiety groupings. ${ }^{50}$ Also of possible relevance is the fact that this region is close to a number of binary classification systems: those involving contrasting birds in Victorian languages, hot versus cold winds in the area west of the Darling and two kinds of bloods east of the Darling.

49 Cf. the comment by Blake et al. (2011, p. 25): 'This system [of Kilpara and Makwara moieties] is closely linked with the matrilineal moiety Kararru/Mathari and ThiniwalKulpari systems of the people to the northwest and north of the Paakantyi in South Australia and adjacent parts of Queensland as described by Elkin (1931) and so the area under discussion forms part of a much larger region of matrilineal moieties'.

50 Clark and Ryan (2009) document from a number of early sources the many disparate groups that occupied the Murray River area between the junctions of the Murrumbidgee and Darling rivers. 
If the hints about the possible original meanings of the Darling River names, in terms of hot and cold winds mentioned at the end of the subsection 'Other Two-Term Terminology Sets', reflect reality, this supports the Paakantyi language as being the source of these names. Figure 22 presents a possible scenario for the spread of naming sets.

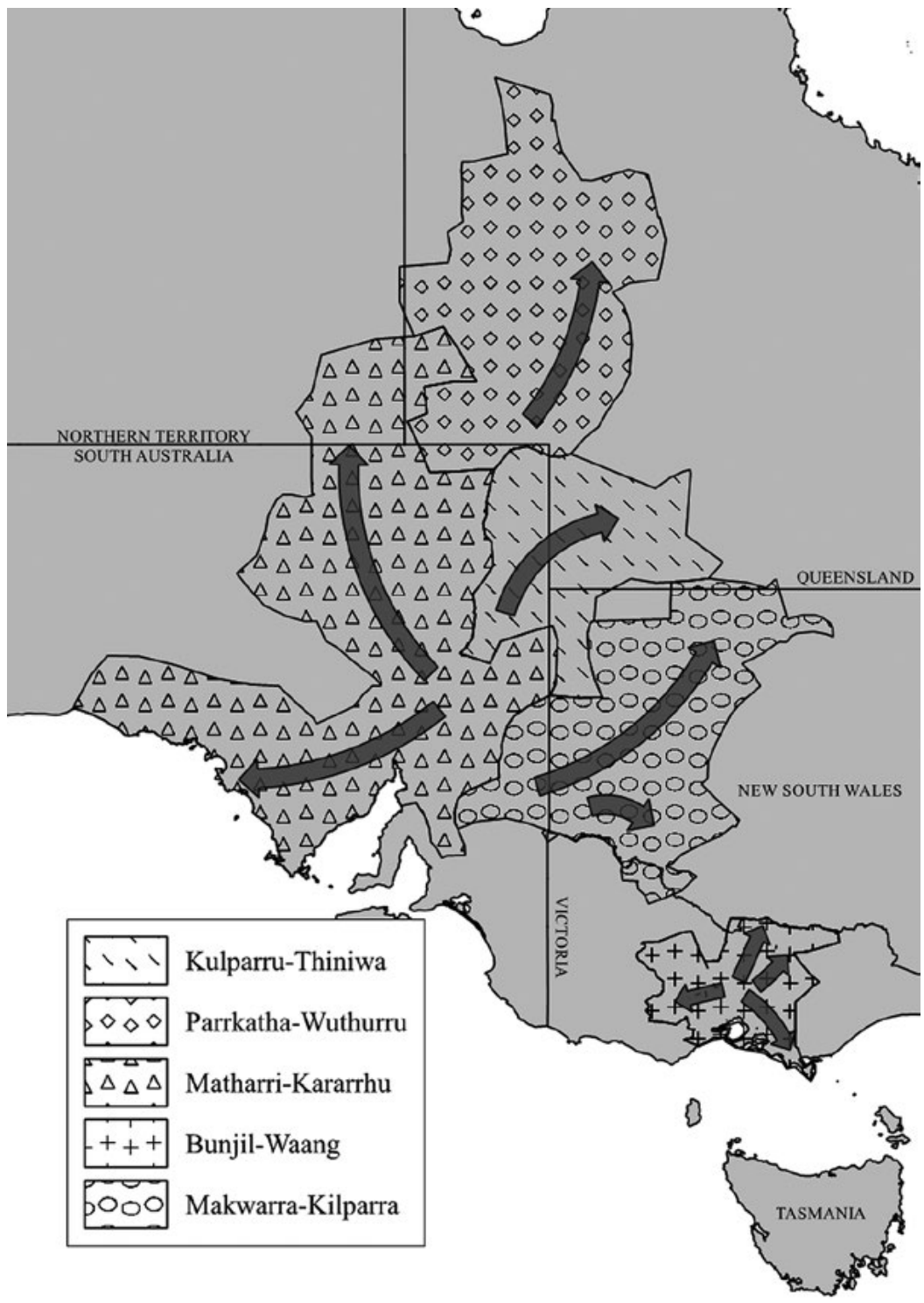

Figure 22: Distribution and spread of moiety name sets.

Source: Authors' work. 


\section{Origin of Moiety Systems}

Separate from the question of where specific moiety names originated and in what direction they spread is the issue of how moiety systems arose in the first instance. This question is complicated by the fact that a large number of languages to the north and east of the bloc that concerns us had a system of four sections, often along with matrimoiety names (see Figure 21; Chapter 8). It has been assumed that four-section systems are a later development from moiety systems (e.g. Fison \& Howitt 1880, p. 37). Hence, it is possible that sets of moiety names existed earlier in languages to the north and east of the Darling River and Cooper Basin, and that the naming sets described above have spread from the north or north-east.

Questions of the origin of moiety systems are further complicated by their widespread distribution in the Australian continent. Besides the areas discussed here, they have been reported in the far south-west of Western Australia, the Kimberley, western and central parts of the Top End and the Cape York Peninsula (Berndt \& Berndt 1981, pp. 55-6). Further, many of the regions that now have sections or subsections may have earlier had moiety systems. Hence, it is possible that moieties were created independently in different areas. It is also possible that the names of moieties may have been replaced over time- that is, the most recently attested names were not the only names that were used throughout the history of the system. ${ }^{51}$

\section{The Etymology of Moiety Names}

Although we might legitimately assume that the names were once meaningful in the language in which they originated, these origins are now largely inaccessible due to the sparse documentation of vocabularies of these languages, as well as the passage of time, which typically leads to changes in the form and meaning of words. Even within the existing record, it is not always possible to isolate the most relevant languages

51 See, for example, the different reports by Elkin and Beckett concerning the moiety names of the Malyangapa mentioned in the subsection 'Other Two-Term Terminology Sets'. Similarly, the difference between moiety names reported for Gamilaraay around 1900 by Mathews and Howitt-Dhilbi and Kupathin — and those given by the modern dictionary (Ash et al. 2003) — Wudhurruu and Yanguu (see Wafer \& Lissarrague 2008, p. 453) — probably reflect a replacement during the twentieth century. 
and semantic domains. However, some clues can be gained from the kinds of concepts that are used to describe the various systems of dual classification (including moieties) that are found.

Bird names are emblematic of moieties in many parts of Australia-for example, white cockatoo and crow in the south-west (Bates 1985, pp. 74, 192) and in northern Australia (cf. Chapter 8). In our area, we have noted 'eaglehawk' and 'crow' in the East Kulin and Alpine areas and 'corella' and 'black cockatoo' in south-western Victoria. For the Wangaaypuwan, Radcliffe-Brown (1923, p. 425) reported that kuru (bandicoot) is the head of the Muämbuän division and the turu (brown snake) is the head of the Därawän division..$^{52}$ It is possible that a totem name may be promoted or elevated to represent a whole moiety, as suggested at the end of the section 'The Western Victorian Set' (cf. Wiradjuri moiety name Budthurung, which is also the name of a totem, 'black duck', as mentioned in subsection 'Other Two-Term Terminology Sets').

Features other than species names that are sometimes used in dual classification systems may have provided a source for moiety names. Opposite physical characteristics of totemic creatures or human beings may be the basis for classification. Features that have been cited include dark versus light complexion for the people of Fowlers Bay (cited in Hercus 1999, p. 1), slender versus heavier/broader features among the Adnyamathanha (Schebeck 1973, p. 24), straight versus wavy hair among the Arrernte (Spencer \& Gillen 1927, p. 42), fur versus scales or slow versus quick blood in western New South Wales (Radcliffe-Brown 1923, p. 425$).{ }^{53}$

Further, the location of the camping areas of social groups may be employed in a classification: upper versus lower section of a tree or the light versus dark shade therefrom among the Wangaaypuwan (RadcliffeBrown 1923, p. 425), or water-dwellers versus land-dwellers among the Arrernte (Carl Strehlow in Spencer \& Gillen 1927, p. 41).

52 Radcliffe-Brown qualified this statement: 'This is according to the statement of a man of the bandicoot clan, and it is possible that men of other clans might give different statements'. One might infer from this comment that which totem 'heads' one of the two divisions may be subject to competition between social groups and hence liable to variability over time.

53 This fact was used by Mathew (1910) in support of his theory that moieties originated from the amalgamation of two distinct races. 
Meteorological contrasts have also been reported as the basis for dual classification: the hot west or north versus the cold east or south wind has been mentioned for Paakantyi (Hercus 1993, p. 32), Malyangapa (Beckett 1967, p. 457) and Adnyamathanha (Schebeck 1973, p. 25). The Kiabara (of south-east Queensland) [Kyabra on modern maps] moieties Dilebi and Cubatine were associated with floodwater and lightning respectively, according to Howitt (1884, p. 336). These meteorological classifications suggest some etymologies for moiety names. In the subsection 'Other Two-Term Terminology Sets', we proposed a possible etymological link between the moiety name Makuwarra (and other terms based on maku-) and the Paakantyi (Paaruntyi dialect) term makurra for 'cold weather'. The Kiabara information suggests that one could compare the Wangkumara moiety name Thiniwa with the term tyiniwara 'thunder' in the same language (McDonald \& Wurm 1979, p. 108), and speculate whether the moiety name here derives from a meteorological term.

\section{Summary and Conclusions}

We have discussed the distribution of six moiety nomenclature terminology sets from south-eastern Australia. We have related the sets of terms to the languages and their genealogical groupings. We have documented the fact that the geographical distribution of naming sets largely fails to match that of linguo-genetic groups. We have taken this as support for a claim that the naming sets have mostly spread subsequent to the diversification of the languages. We have seen some hints concerning the spread of terms through cultural interaction, including intermarriage. We have noted that the moiety name sets are all geographically contiguous to one another and hypothesised that the Darling River is a focal point of these moiety systems and their associated terminology, and hence a candidate for the origin and stimulus for the development of these naming sets in southeastern Australia. Apart from the transparent naming of moieties in a few languages (mostly in Victoria), the names lack clear etymologies. Nevertheless, we have made some suggestions regarding plausible semantic domains from which the names may have been derived, including bird names, physical features of people and meteorological elements. There is the possibility that some moiety names represent totemic names that have been promoted in a classification hierarchy-as suggested by the western Victorian bird names (see the section 'The Western Victorian Set'). We refrain from speculation on how, where or when moiety systems as 
a general principle of social organisation originated; and we leave for the future any discussion and evaluation of the various theories that have been proposed since the 1880s. Our study has benefited from, and illustrates the value of, an interdisciplinary approach that combines evidence from anthropology, history, geography and linguistics (both descriptive and historical) to arrive at plausible scenarios to explain the moiety naming systems of south-eastern Australia, which has been a subject of interest since the latter part of the nineteenth century.

\section{References}

Ash, A, Giacon, J \& Lissarrague, A (eds) 2003, Gamilaraay, Yuwaalaraay, and Yuwaalayaay dictionary, Alice Springs, NT: IAD Press.

Austin, P 1981, A grammar of Diyari, South Australia, Cambridge: Cambridge University Press.

AustKin 2017, The AustKin project, viewed 31 July 2017, www.austkin.net.

Australian Institute of Aboriginal and Torres Strait Islander Studies (AIATSIS) 2017, Welcome to AUSTLANG, viewed 31 July 2017, austlang.aiatsis.gov.au.

Barwick, DE 1984, 'Mapping the past: an atlas of Victorian clans 18351904', Aboriginal History, 8, pp. 100-31.

Barwick, DE 1998, in LE Barwick \& RE Barwick (eds), Rebellion at Coranderrk, Aboriginal History Monograph 5, Canberra: Aboriginal History Inc.

Bates, D 1985, in I White (ed.) The native tribes of Western Australia, Canberra: National Library of Australia.

Beckett, J 1967, 'Marriage, circumcision and avoidance among the Maljangaba of New South Wales', Mankind, 6, pp. 456-64. doi.org/ 10.1111/j.1835-9310.1967.tb01348.x.

Berndt, RM 1939, 'A curlew and owl legend from the Narunga tribe, South Australia', Oceania, 10, pp. 456-62. doi.org/10.1002/j.18344461.1940.tb00306.x.

Berndt, RM (ed.) 1964, Australian Aboriginal art, Sydney: Ure Smith. 
Berndt, RM \& Berndt CH 1981, The world of the First Australians, Revised edition, Sydney: Lansdowne Press.

Blake, BJ 1979, A Kalkatungu grammar, Pacific Linguistics B-57, Canberra: The Australian National University.

Blake, BJ 1991, 'Woiwurrung, the Melbourne language', in RMW Dixon \& BJ Blake (eds), Handbook of Australian languages volume 4: the Aboriginal language of Melbourne and other grammatical sketches, Melbourne: Oxford University Press, pp. 30-122.

Blake, BJ 2003a, The Bunganditj (Buwandik) language of the Mount Gambier region, Pacific Linguistics 549, Canberra: The Australian National University.

Blake, BJ 2003b, The Warrnambool language: a consolidated account of the language of the Warrnambool area of the Western District of Victoria based on nineteenth-century sources, Pacific Linguistics 544, Canberra: The Australian National University.

Blake, BJ 2011, Dialects of western Kulin, western Victoria: Yartwatjali, Tjapwurrung, Djadjawurrung, Unpublished manuscript, Melbourne: La Trobe University.

Blake, BJ \& Breen, JG 1971, The Pitta-Pitta dialects, Linguistic Communications 4, Melbourne: Monash University.

Blake, BJ, Clark, I \& Krishna-Pillay, SH 1998, 'Wathawurrung: the language of the Geelong-Ballarat area', in BJ Blake (ed.), Wathawurrung and the Colac language of southern Victoria, Pacific Linguistics C-147, Canberra: The Australian National University, pp. 59-154.

Blake, BJ, Hercus, L, Morey, S \& Ryan, E 2011, The Mathi group of languages, Pacific Linguistics 628, Canberra: The Australian National University.

Blake, BJ \& Reid, J 1998, 'Classifying Victorian languages', in Barry J. Blake (ed.), Wathawurrung and the Colac language of southern Victoria, Pacific Linguistics C-147, Canberra: The Australian National University, pp. 1-58.

Blake, BJ \& Reid, J 1999, 'Pallanganmiddang, a language of the upper Murray', Aboriginal History, 23, pp. 15-31. 
Bowe, H \& Morey, S 1999, The Yorta Yorta (Bangerang) language of the Murray Goulburn, including Yabula Yabula, Pacific Linguistics C-154, Canberra: The Australian National University.

Bowern, C 1999, A sketch grammar of Nhirrpi, Unpublished manuscript.

Bowern, C 2001, 'Karnic classification revisited', in J Simpson et al. (eds), Forty years on: Ken Hale and Australian languages, Pacific Linguistics 512, Canberra: The Australian National University, pp. 245-61.

Bowern, C 2009, 'Reassessing Karnic: a reply to Breen (2007)', Australian Journal of Linguistics, 29(3), pp. 337-48. doi.org/ 10.1080/07268600903232733.

Breen, JG 1971, Aboriginal languages of western Queensland, Linguistic Communications 5, Melbourne: Monash University, pp. 1-88.

Breen, JG 1981a, 'Margany and Gunya', in RMW Dixon \& BJ Blake (eds), Handbook of Australian languages vol. 2, Canberra: The Australian National University Press, pp. 274-393. doi.org/ 10.1075/z.hal2.08bre.

Breen, JG 1981b, The Mayi languages of the Queensland Gulf Country, Canberra: Australian Institute of Aboriginal Studies.

Breen, JG 2004a, Innamincka talk: a grammar of the Innamincka dialect of Yandruwandha with notes on other dialects, Pacific Linguistics 558, Canberra: The Australian National University.

Breen, JG 2004b, Innamincka words: Yandruwandha dictionary and stories, Pacific Linguistics 559, Canberra: The Australian National University.

Breen, JG \& Blake, BJ 2007, The grammar of Yalarnnga: A language of western Queensland, Pacific Linguistics 584, Canberra: The Australian National University.

Clark, ID 1990, Aboriginal languages and clans: an historical atlas of western and central Victoria, 1800-1900, Monash Publications in Geography 37, Melbourne: Department of Geographical and Environmental Sciences, Monash University.

Clark, I \& Ryan, E 2009, 'Ladjiladji language area: A reconstruction', Australian Aboriginal Studies, 1, pp. 77-88. 
Davidson, DS 1928, The chronological aspects of certain Australian social institutions: as inferred from geographical distribution, Philadephia: University of Pennsylvania.

Dawson, J 1981 [1881], Australian Aborigines: the languages and customs of several tribes of Aborigines in the Western District of Victoria, Australian, Facisimile edition, Canberra: Australian Institute of Aboriginal Studies.

Dixon, RMW 2002, The Australian languages: their nature and development, Cambridge: Cambridge University Press. doi.org/ 10.1017/CBO9780511486869.

Eira, C 2008, 'Not tigers-sisters! Advances in the interpretation of historical sources for Dhudhuroa and Waywurru', Aboriginal History, 32, pp. 151-64.

Elkin, AP 1931, 'The social organization of South Australian tribes', Oceania, 2, pp. 44-73. doi.org/10.1002/j.1834-4461.1931.tb 00022.x.

Elkin, AP 1964, The Australian Aborigines: how to understand them, 4th edn, Sydney: Angus \& Robertson.

Fison, L \& Howitt, AW 1880, Kamilaroi and Kurnai: group-marriage and relationship, and marriage by elopement, Melbourne: George Robertson.

Furphy, S 2013, Edward M. Curr and the tide of history, Canberra: ANU E Press.

Hercus, LA 1982, The Baagandji language, Pacific Linguistics B-67, Canberra: The Australian National University.

Hercus, LA 1986, Victorian languages: a late survey, Pacific Linguistics B-77, Canberra: The Australian National University.

Hercus, LA 1991, 'Glimpses of the Karangura', Records of the South Australian Museum, 25(2), pp. 139-59.

Hercus, LA 1992a, A Nukunu dictionary, Canberra: Luise Hercus with the assistance of AIATSIS.

Hercus, LA 1992b, Wembawemba dictionary, Canberra: Luise Hercus with the assistance of AIATSIS. 
Hercus, LA 1993, Paakantyi dictionary, Canberra: Luise Hercus with the assistance of AIATSIS.

Hercus, LA 1999, A grammar of Wirangu, a language of the west coast of South Australia, Pacific Linguistics C-150, Canberra: The Australian National University.

Hercus, LA \& Austin, P 2004, 'The Yarli languages', in C Bowern $\& \mathrm{H}$ Koch (eds), Australian languages: classification and the comparative method, Amsterdam/Philadelphia: John Benjamins, pp. 207-22, 647-54. doi.org/10.1075/cilt.249.13her.

Hercus, LA \& Simpson, J 2001, 'The tragedy of Nauo', in Jane Simpson et al. (eds), Forty years on: Ken Hale and Australian languages, Pacific Linguistics 512, Canberra: The Australian National University, pp. 263-90.

Horgen, M 2004, The languages of the lower-Murray, MA thesis, La Trobe University.

Howitt, AW 1883, 'Notes on the Australian class systems', The Journal of the Anthropological Institute of Great Britain and Ireland, 12, pp. 496-512. doi.org/10.2307/2841688.

Howitt, AW 1884, 'Remarks on the class systems collected by Mr. Palmer', The Journal of the Anthropological Institute of Great Britain and Ireland, 13, pp. 335-46.

Howitt, AW 1996 [1904], The native tribes of south-east Australia, Facsimile edition, Canberra: Aboriginal Studies Press.

Koch, H 2012, 'Aboriginal languages and social groups in the Canberra region: interpreting the historical documentation', in B Baker et al. (eds), Indigenous language and social identity: papers in honour of Michael Walsh, Pacific Linguistics 626, Canberra: The Australian National University, pp. 123-44.

Mathew, J 1910, 'The origin of the Australian phratries and explanation of some of the phratry names', The Journal of the Anthropological Institute of Great Britain and Ireland, 40, pp. 164-70. doi.org/ $10.2307 / 2843147$. 
Mathews, RH 1898, 'The Victorian Aborigines: their initiation ceremonies and divisional systems', American Anthropologist, 11, pp. 325-43. doi.org/10.1525/aa.1898.11.11.02a00000.

Mathews, RH 1900, 'Divisions of the South Australian Aborigines', Proceedings of the American Philosophical Society, 39, pp. 78-91, 93.

Mathews, RH 1903, 'Some Aboriginal languages of Queensland and Victoria', Proceedings of the American Philosophical Society, 42(173), pp. 179-88.

Mathews, RH 1905, 'Ethnological notes on the Aboriginal tribes of Queensland', Royal Geographical Society of Australasia, Queensland, 20, pp. 49-75.

McConvell, P 2013, 'Granny got cross: semantic change of kami "mother's mother" to "father's mother" in Pama-Nyungan', in R Mailhammer (ed.), Lexical and structural etymology: beyond word histories, Berlin: de Gruyter Mouton, pp. 147-84. doi.org/10.1515/9781614510581.147.

McConvell, P \& Dousset, L 2012, 'Tracking the dynamics of kinship and social category terms with AustKin II', Proceedings of the EACL 2012 Joint Workshop of LINGVIS \& UNCLH, Avignon, France, 23-24 April 2012, pp. 98-107.

McDonald, M \& Wurm, SA 1979, Basic materials in Waykumara (Galali): grammar, sentences and vocabulary, Pacific Linguistics B-65, Canberra: The Australian National University.

Oates, LF 1988a, Barranbinya: fragments of a N.S.W. language. Papers in Australian linguistics No. 17, Pacific Linguistics A-71, Canberra: The Australian National University, pp. 185-204.

Oates, LF 1988b, The Muruwari language, Pacific Linguistics C-108, Canberra: The Australian National University.

Radcliffe-Brown, AR 1918, 'Notes on the social organization of Australian tribes. Part 1', Journal of the Royal Anthropological Institute of Great Britain and Ireland, 48, pp. 222-53. doi.org/10.2307/2843422.

Radcliffe-Brown, AR 1923, 'Notes on the social organization of Australian tribes', Journal of the Royal Anthropological Institute of Great Britain and Ireland, 53, pp. 424-46. doi.org/10.2307/2843580. 
Radcliffe-Brown, AR 1930-31, The social organization of Australian tribes, Oceania Monographs 1, Sydney: University of Sydney.

Reay, M 1945, Bakundji (from Hero Black at Bourke, 1945), Unpublished manuscript, AIATSIS: Canberra.

Robertson, C 1984, Wangkumara grammar and dictionary, Unpublished manuscript, Haymarket: NSW.

Roth, WE 1984 [1897], Ethnological studies among the north-west-central Queensland Aborigines, Facsimile edition, The Queensland Aborigines vol. 1, Victoria Park, WA: Hesperian Press.

Schebeck, B 1973, The Adnjamathanha personal pronoun and the 'Wailpi kinship system. Papers in Australian linguistics no. 6, Pacific Linguistics A-36, Canberra: The Australian National University, pp. 1-45.

Scheffler, HW 1978, Australian kin classification, Cambridge: Cambridge University Press. doi.org/10.1017/CBO9780511557590.

Simpson, J \& Hercus, L 2004, 'Thura-Yura as a subgroup', in C Bowern \& H Koch (eds), Australian languages: classification and the comparative method, Amsterdam/Philadelphia: John Benjamins, pp. 179-206, 581-645. doi.org/10.1075/cilt.249.12sim.

Smyth, RB 1878, The aborigines of Victoria: with notes relating to the habits of the natives of other parts of Australia and Tasmania, Melbourne: Government Printer.

Spencer, B \& Gillen, FJ 1927, The Arunta: a study of a Stone Age people, 2 vols, London: Macmillan.

Testart, A 1978, Des classifications dualistes en Australie: Essai sur l'évolution de l'organisation sociale, Paris: Editions de la Maison des sciences de l'homme et Publications de l'université de Lille III.

Wafer, J \& Lissarrague, A 2008, A handbook of Aboriginal languages of New South Wales and the Australian Capital Territory, Nambucca Heads, NSW: Muurrbay Aboriginal Language and Cultural Co-operative. 
This text is taken from Skin, Kin and Clan: The dynamics of social categories in Indigenous Australia, edited by Patrick McConvell, Piers Kelly and Sébastien Lacrampe, published 2018 by ANU Press, The Australian National University, Canberra, Australia.

doi.org/10.22459/SKC.04.2018.06 